\title{
The Quenching and Sonication Effect on the Mechanical Strength of Silver Nanowires Synthesized Using the Polyol Method
}

\author{
Junaidi Junaidi ${ }^{1,2, *}$, Muhamad Wahyudi Saputra ${ }^{1}$, Roniyus Marjunus ${ }^{1}$, Simon Sembiring ${ }^{1}$ and Sutopo Hadi ${ }^{3}$ \\ 1 Department of Physics, Faculty of Mathematics and Natural Sciences, Universitas Lampung, \\ Bandar Lampung 35145, Indonesia; mwsaputra31@gmail.com (M.W.S.); \\ roniyus.1977@fmipa.unila.ac.id (R.M.); simon.sembiring@fmipa.unila.ac.id (S.S.) \\ 2 Instrumentation Research Group, Department of Physics, Faculty of Mathematics and Natural Sciences, \\ Universitas Lampung, Bandar Lampung 35145, Indonesia \\ 3 Department of Chemistry, Faculty of Mathematics and Natural Sciences, Universitas Lampung, \\ Bandar Lampung 35145, Indonesia; sutopo.hadi@fmipa.unila.ac.id \\ * Correspondence: junaidi.1982@fmipa.unila.ac.id
}

Citation: Junaidi, J.; Saputra, M.W.; Marjunus, R.; Sembiring, S.; Hadi, S. The Quenching and Sonication Effect on the Mechanical Strength of Silver Nanowires Synthesized Using the Polyol Method. Molecules 2021, 26, 2167. https://doi.org/10.3390/ molecules26082167

Academic Editor: Tibor Pasinszki

Received: 12 March 2021

Accepted: 8 April 2021

Published: 9 April 2021

Publisher's Note: MDPI stays neutral with regard to jurisdictional claims in published maps and institutional affiliations.

Copyright: (c) 2021 by the authors. Licensee MDPI, Basel, Switzerland. This article is an open access article distributed under the terms and conditions of the Creative Commons Attribution (CC BY) license (https:/ / creativecommons.org/licenses/by/ $4.0 /)$.

\begin{abstract}
This study aims to determine the effect of fast cooling (quenching) on thermal properties, mechanical strength, morphology and size of the AgNWs. The synthesis of AgNWs was carried out at three different quenching-medium temperatures as follows: at $27^{\circ} \mathrm{C}$ (ambient temperature), $0{ }^{\circ} \mathrm{C}$ (on ice), and $-80^{\circ} \mathrm{C}$ (in dry ice) using the polyol method at $130^{\circ} \mathrm{C}$. Furthermore, the AgNWs were sonified for $45 \mathrm{~min}$ to determine their mechanical strength. Scanning electron microscopy analysis showed that the quenched AgNWs had decreased significantly; at $27^{\circ} \mathrm{C}$, the AgNWs experienced a change in length from $(40 \pm 10)$ to $(21 \pm 6) \mu \mathrm{m}$, at $0{ }^{\circ} \mathrm{C}$ from $(37 \pm 8)$ to $(24 \pm 8) \mu \mathrm{m}$, and at $-80{ }^{\circ} \mathrm{C}$ from $(34 \pm 9)$ to $(29 \pm 1) \mu \mathrm{m}$. The opposite occurred for their diameter with an increased quenching temperature: at $27^{\circ} \mathrm{C}$ from $(200 \pm 10)$ to $(210 \pm 10) \mathrm{nm}$, at $0{ }^{\circ} \mathrm{C}$ from $(224 \pm 4)$ to $(239 \pm 8) \mathrm{nm}$, and at $-80{ }^{\circ} \mathrm{C}$ from $(253 \pm 6)$ to $(270 \pm 10) \mathrm{nm}$. The lower the temperature of the quenching medium, the shorter the length and the higher the mechanical strength of AgNWs. The UV-Vis spectra of the AgNWs showed peak absorbances at 350 and 411 to $425 \mathrm{~nm}$. Thermogravimetric analysis showed that AgNWs quenched at $-80{ }^{\circ} \mathrm{C}$ have better thermal stability as their mass loss was only $2.88 \%$, while at the quenching temperatures of $27^{\circ} \mathrm{C}$ and $0{ }^{\circ} \mathrm{C}$ the mass loss was of $8.73 \%$ and $4.17 \%$, respectively. The resulting AgNWs will then be applied to manufacture transparent conductive electrodes (TCEs) for optoelectronic applications.
\end{abstract}

Keywords: characterization; polyol; quenching; silver nanowires; synthesis

\section{Introduction}

In the last decade, nanotechnology research has attracted the attention of researchers and academics in developing new technologies from materials that have good physical properties [1,2]. Nanotechnology is the manipulation of atoms and molecules to produce materials below the sub-macroscopic level $[3,4]$. The advantage of these nanostructured materials is the uniqueness of their mechanical, electronic, optical, and magnetic properties, which are different from those of micro or macro-sized materials [5,6]. However, an important factor in the development of nanotechnology is the synthesis of a material to obtain a nano-sized material.

The research on nanotechnology that is currently being developed is nanowires (NWs). NWs are one-dimensional nanostructures that have diameters of less than $100 \mathrm{~nm}$ and range in length from hundreds of nanometers to several micrometers [7]. NWs are considered to be promising materials because of their wide applications, such as in energy [7-11], environmental [12], health [13], sensor [14-17] and optoelectronics [17-19]. 
The synthesis of NWs requires the assistance of metal precursors. The metals that have were used are gold [20], silver (Ag) [21-27], and copper [28]. However, Ag is more widely used because of its high electrical and thermal conductivities, which are $6.310^{7} \mathrm{~S} \mathrm{~m}^{-1}$ and $429 \mathrm{~W} \mathrm{~m}^{-1} \mathrm{~K}^{-1}$, respectively [29-33]. Ag-based NWs (AgNWs) are well-established as transparent conductive electrodes [34-36].

Studies on the synthesis of AgNWs using the polyol method have been carried out by varying several other parameters, such as the oil bath temperature and the reaction time, the molecular weight of the capping agent, the molar ratio, the injection rate, the stirring rate, and the salt precursor; each parameter influences the size and properties of the AgNWs. One variation that has not been tried is that of the quenching medium during the final step of the synthesis process. Therefore, investigated the effects of three different quenching-medium temperatures, namely at $27^{\circ} \mathrm{C}$ (in water), $0{ }^{\circ} \mathrm{C}$ (in ice), and $-80{ }^{\circ} \mathrm{C}$ (in dry ice), on AgNW synthesis. The AgNWs were characterized using UV-Vis spectroscopy, scanning electron microscopy (SEM), transmission electron microscopy (TEM), differential thermal analysis (DTA), and thermogravimetric analysis (TGA).

\section{Results}

\subsection{UV-Vis Analysis}

To analyze the optical properties of the AgNWs, UV-Vis spectroscopy has been utilized. Pure AgNWs are known to have a peak in the wavelength region between 350-390 nm [21, 31,33,37-39]. The UV-Vis spectra of the AgNWs samples are shown in Figure 1.

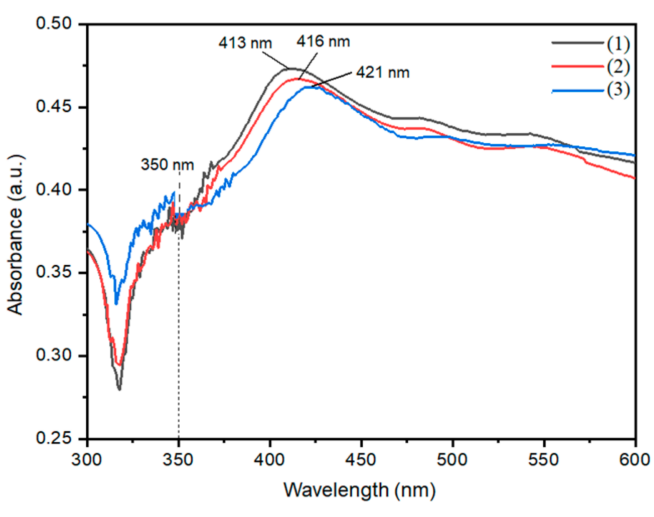

(a)

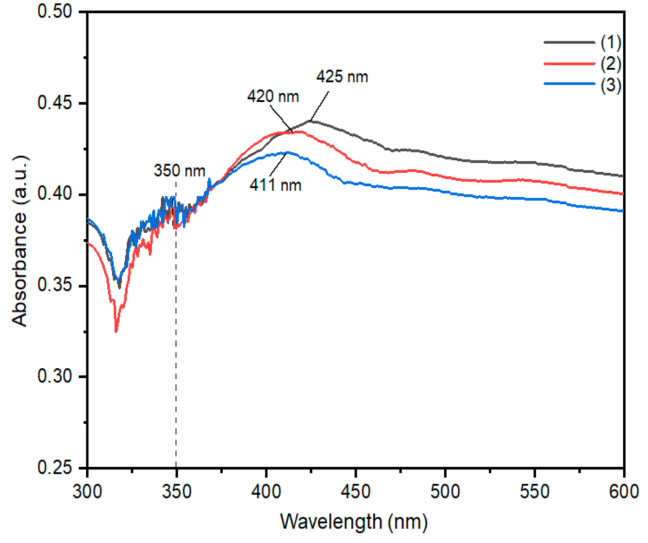

(b)

Figure 1. UV-Vis spectrum of AgNWs samples: (a) before being vibrated and (b) after being vibrated by (1) water medium, (2) ice medium, and (3) dry ice medium.

\subsection{SEM and TEM Analysis}

SEM analysis was used to determine the morphology and size of the AgNWs. The samples that were characterized were samples from each variation of the temperature of the quenching medium and the vibrating effect using an ultrasonic cleaner. The SEM results were analyzed using the ImageJ application to find out the length and diameter of the AgNWs in each sample. The results of SEM characterization are shown in Figure 2. The TEM images and relationship between the temperature of the quenching medium of AgNWs are shown in Figures 3 and 4. 

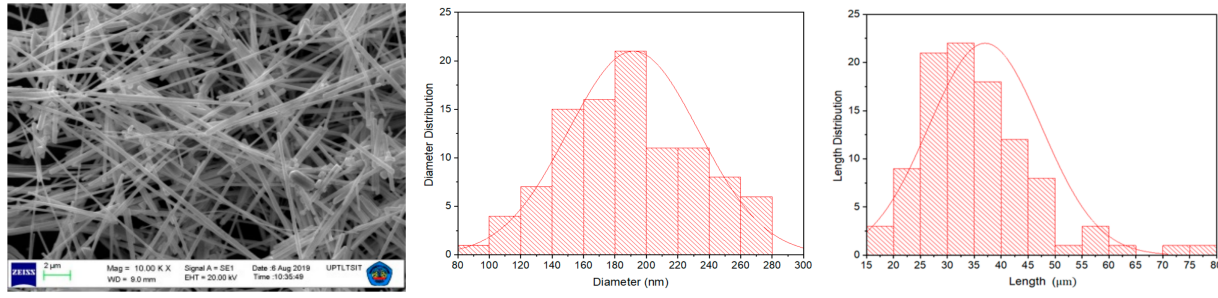

(a)
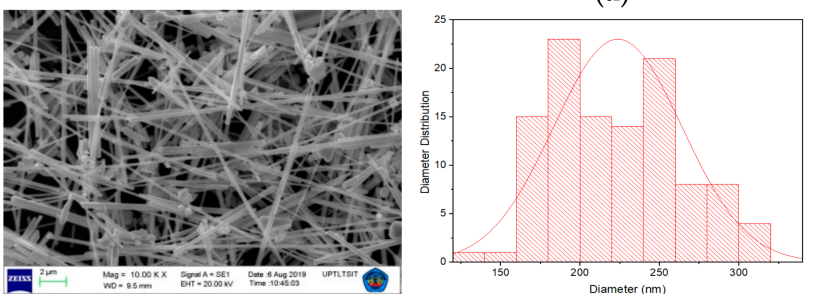

(b)
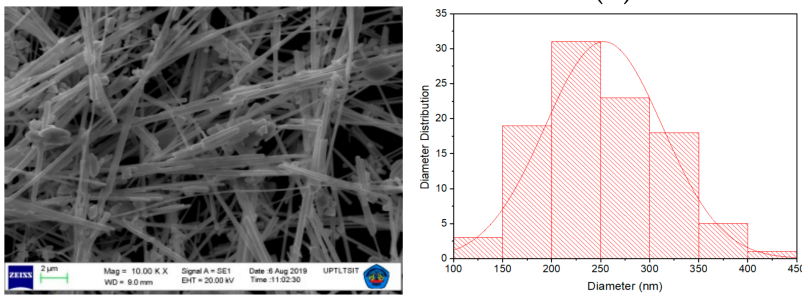

(c)
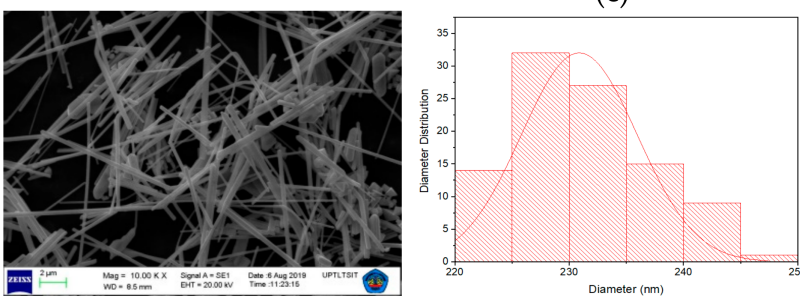

(d)
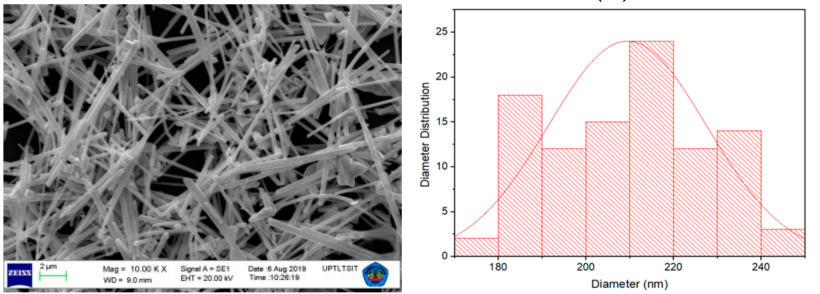

(e)
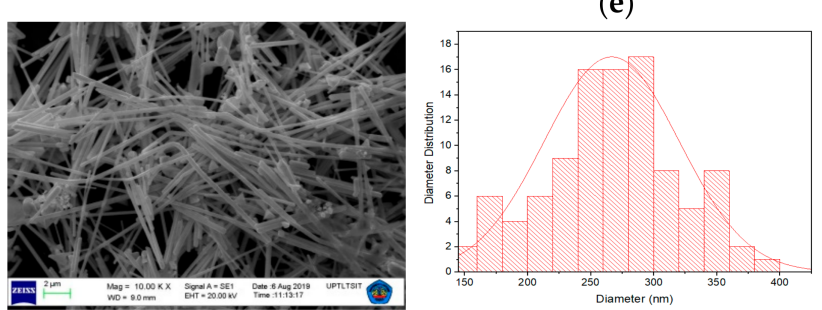

(f)
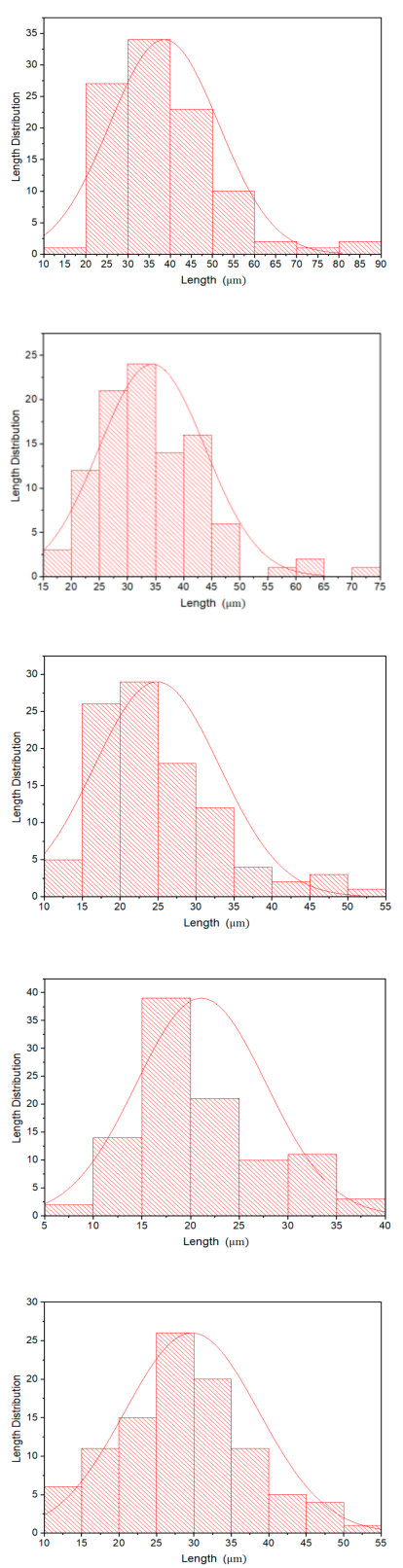

Figure 2. SEM images the morphology of AgNWs at quenching medium temperature (a) $27^{\circ} \mathrm{C}$, (b) $0{ }^{\circ} \mathrm{C}$, (c) $-80{ }^{\circ} \mathrm{C}$, (d) $27^{\circ} \mathrm{C}$ was vibrated, (e) $0{ }^{\circ} \mathrm{C}$ was vibrated, and (f) $-80{ }^{\circ} \mathrm{C}$ was vibrated. 


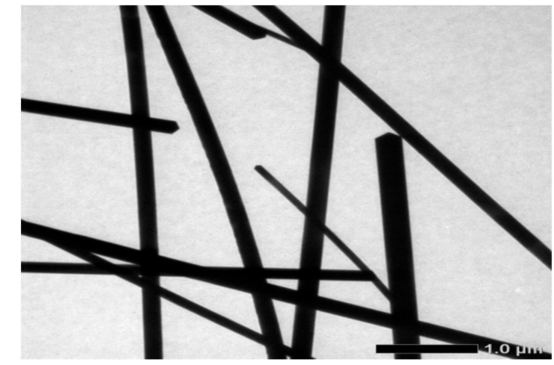

(a)

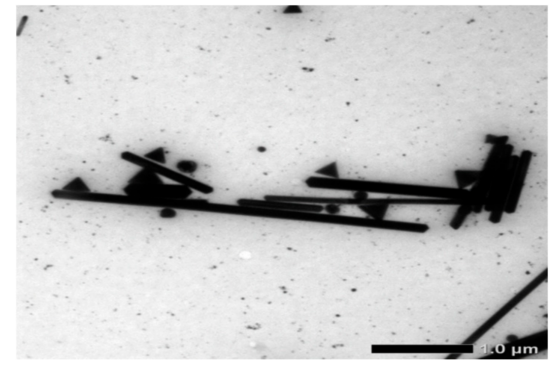

(b)

Figure 3. TEM images of AgNWs at quenching medium temperature $27^{\circ} \mathrm{C}$. (a) non-vibrated and (b) vibrated.

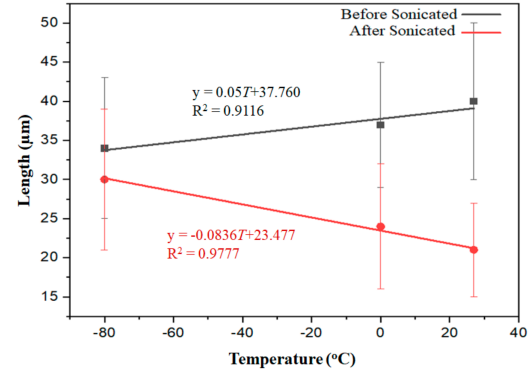

(a)

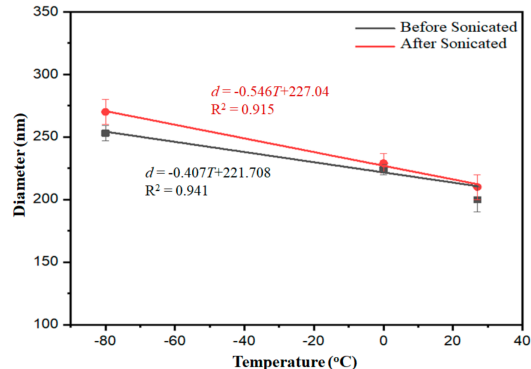

(b)

Figure 4. The relationship between the temperature of the quenching medium with (a) the length of AgNWs, and (b) the diameter of AgNWs.

\subsection{DTA/TGA Analysis}

A thermal analysis of the AgNWs was performed using DTA/TGA. DTA/TGA analysis was carried out at a heating speed of $10^{\circ} \mathrm{C} / \mathrm{min}$ over a temperature range of $30^{\circ} \mathrm{C}$ to $500{ }^{\circ} \mathrm{C}$. The DTA/TGA analysis results are shown in Figure 5 and Table 1.

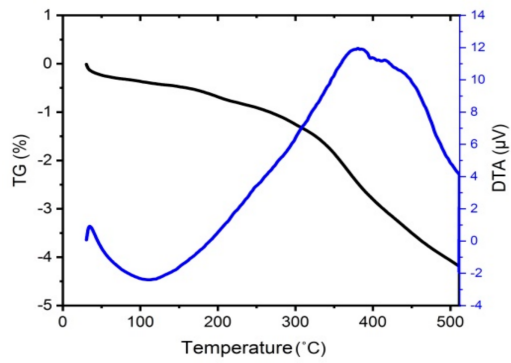

(a)

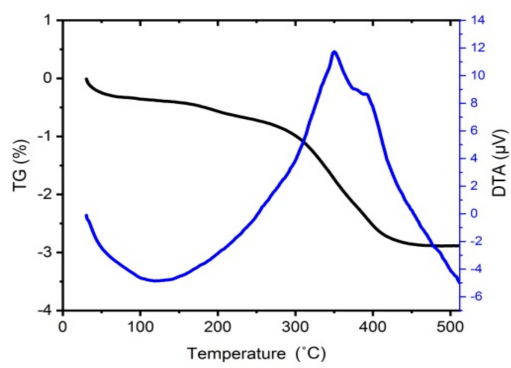

(c)

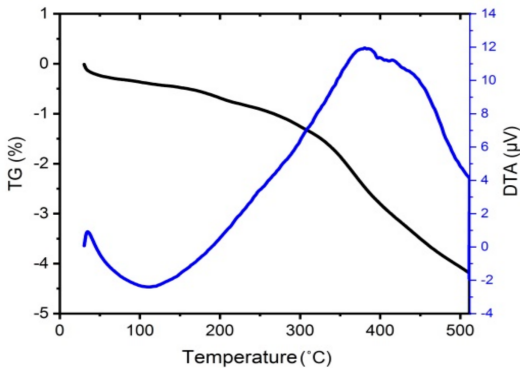

(b)

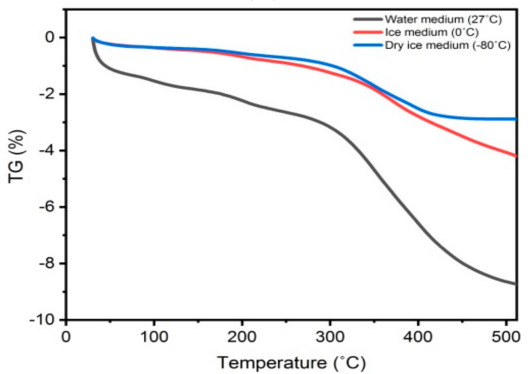

(d)

Figure 5. DTA/TGA AgNWs test results were quenched at temperature (a) $27^{\circ} \mathrm{C},(\mathbf{b}) 0{ }^{\circ} \mathrm{C},(\mathbf{c})-80^{\circ} \mathrm{C}$, and (d) comparison of the percentage of mass loss based on TGA characterization. 
Table 1. DTA/TGA characterization.

\begin{tabular}{cccc}
\hline Medium & Temperature $\left({ }^{\circ} \mathbf{C}\right)$ & Heat Process & Loss Mass (\%) \\
\hline \multirow{2}{*}{ Water } & $30-330$ & Endothermic & 3.94 \\
& $330-500$ & Exothermic & 4.71 \\
\hline \multirow{2}{*}{ Ice } & $30-330$ & Endothermic & 1.54 \\
& $330-500$ & Exothermic & 2.53 \\
\hline \multirow{2}{*}{ Dry Ice } & $30-330$ & Endothermic & 1.35 \\
& $330-500$ & Exothermic & 1.53 \\
\hline
\end{tabular}

\section{Discussion}

From the UV-Vis analysis in Figure 1b, it is shown that all AgNW samples have two absorption peaks, namely a weak absorption peak at $350 \mathrm{~nm}$ and a strong absorption peak at 411 to $425 \mathrm{~nm}$. These results indicate that the samples are not pure but rather consist of a mixture of AgNWs and AgNPs [28-32]. As observable in the spectra in Figure 1a, there is a shift in the wavelength (red shift) from 413 to $421 \mathrm{~nm}$ due to the increasing diameter of the AgNWs [40-42]. The decrease in absorbance shown in Figure 1 is caused by the decreasing length of the AgNWs due to the vibrational effect [37,43]. An additional broad shoulder appears in the peak above of $400 \mathrm{~nm}$, which results from the distribution of possible orientations of the nanowires with respect to the incident light. Additional minor lifting of the red range of the spectrum is attributed to coupling to travelling plasmons along the nanowire and coagulation of particles, also known from spherical nanoparticles [16].

As seen in Figure 2, it appears that all AgNW samples produce the shape of NWs and some surrounding nanoparticles, and produce different lengths and diameters. These results are in accordance with the UV-Vis spectra shown in Figure 1. AgNWs synthesized at different quenching-medium temperatures are shown in Figure 2a-c. AgNWs quenched at $27^{\circ} \mathrm{C}$ had a length and diameter of $(40 \pm 10) \mu \mathrm{m}$ and $(200 \pm 20) \mathrm{nm}$, at $0{ }^{\circ} \mathrm{C}$ of $(37 \pm 8) \mu \mathrm{m}$ and $(224 \pm 4) \mathrm{nm}$, and at $-80^{\circ} \mathrm{C}$ of $(34 \pm 9) \mu \mathrm{m}$ and $(253 \pm 6) \mathrm{nm}$, respectively. These results indicate that a decrease in the average length of the AgNWs is caused by a decrease in the temperature of the quenching medium.

Figure $2 \mathrm{~d}-\mathrm{f}$ shows the results for AgNWs synthesized at different quenching-medium temperatures after the vibration test. A vibration test was carried out to determine the mechanical strength of the AgNWs. The results show that AgNWs synthesized at $27^{\circ} \mathrm{C}$ had a length and diameter of $(21 \pm 6) \mu \mathrm{m}$ and $(210 \pm 10) \mathrm{nm}$, at $0^{\circ} \mathrm{C}$ of $(24 \pm 8) \mu \mathrm{m}$ and $(239 \pm 8) \mathrm{nm}$, and $\mathrm{at}-80^{\circ} \mathrm{C}$ of $(30 \pm 9) \mu \mathrm{m}$ and $(270 \pm 10) \mathrm{nm}$, respectively. Based on these results, one can assume that the vibration test caused breakages in the AgNWs, which in turn rendered them shorter in length. However, the change in AgNW length in each sample was different; the largest change in length occurred in AgNWs quenched at $27^{\circ} \mathrm{C}$, while the smallest occurred in AgNWs quenched at $-80^{\circ} \mathrm{C}$.

Figure 3 shows the TEM results of AgNWs synthesized after quenching at room temperature $\left(27^{\circ} \mathrm{C}\right)$. In the figure, it can be seen that the AgNWs before and after being vibrated experience a change in size in both diameter and length. AgNWs after being shaken, the length will decrease even if the many are destroyed. AgNWs quenched at $27^{\circ} \mathrm{C}$ had a length and diameter of 30-50 $\mu \mathrm{m}$ and 180-220 nm (Figure 3a). After vibrating, the length and diameter of AgNWs became 5-10 $\mu \mathrm{m}$ and 190-230 nm (Figure 3b). The length of AgNWs after vibrating was below $1 \mu \mathrm{m}$. This condition can be said that the vibrating effect can destroy AgNWs and some even become AgNPs and AgNRs. The molecular weight and molar ratio of (PVP:Ag) are very important for controlling the growth and properties of the silver nanowires. The higher molecular weight of PVP, the greater diameter and length of silver nanowires [44].

Figure 4 shows the relationship between the temperature of the quenching medium and the length and diameter of the AgNWs. Figure 4a shows that the lower the temperature of the quenching medium, the lower the length of the AgNWs. The relationship between the temperature of the quenching medium and the length of the AgNWs can be described 
by the line equation. Furthermore, the lower the temperature of the quenching medium, the higher the mechanical strength of the AgNWs, as seen in Figure 4a. Based on Figure 4a, it appears that after the sonication there was a substantial change in AgNW length with increasing temperature of the quenching medium. Figure $4 \mathrm{~b}$ shows that the lower the temperature of the quenching medium the higher the AgNW diameter. The relationship between the temperature of the quenching medium and the diameter of the AgNWs can be described by the line equation in Figure 4 . The sonification caused an increase in diameter, but the change is not significant [45].

Figure 5 shows the results of the thermal analysis of the AgNWs (DTA/TGA curve). The DTA results for all AgNW samples did not differ, that is all samples showed an endothermic peak at a temperature of around $110^{\circ} \mathrm{C}$, which indicates the ethanol evaporation as a dispersant, and an exothermic peak at a temperature of around $360^{\circ} \mathrm{C}$, which indicates the melting and decomposition of PVP. The endothermic and exothermic peaks are followed by the mass loss observed in the TGA curve and can be seen in Table 1 . These results indicate that during the endothermic process, namely the ethanol evaporation process, the AgNWs quenched at $27^{\circ} \mathrm{C}$ experienced a mass loss of $3.94 \%$, while at the quenching temperatures of $0{ }^{\circ} \mathrm{C}$ and $-80{ }^{\circ} \mathrm{C}$, the mass loss was of $1.54 \%$ and $1.35 \%$, respectively. This was also followed by mass loss during the exothermic process, that is the polyvinyl pyrolidone (PVP) melting process. In this case, a lower mass loss was observed when the temperature of the quenching medium was lower; AgNWs that were quenched at $27^{\circ} \mathrm{C}$ underwent a mass loss of $4.71 \%$, while at $0{ }^{\circ} \mathrm{C}$ and $-80{ }^{\circ} \mathrm{C}$ the mass loss was of $2.53 \%$ and $1.53 \%$, respectively.

Figure $5 \mathrm{~d}$ shows the comparison between the mass loss percentages in all three medium samples, i.e., water, ice, and dry ice. The results indicate that the larger total mass loss occurred in the AgNWs sample quenched at $27^{\circ} \mathrm{C}(8.73 \%)$, while AgNWs that were quenched at $0{ }^{\circ} \mathrm{C}$ experienced a total mass loss of $4.19 \%$ and those quenched at $-80{ }^{\circ} \mathrm{C}$ experienced a total mass loss of $2.88 \%$. In Figure $5 \mathrm{~d}$ it can be seen that the lower the temperature of the quenching medium the smaller the percentage of total mass loss of the AgNWs, which means that the thermal stability increases. This is in agreement with the SEM results showing that the lower the temperature of the quenching medium, the higher the mechanical strength of the AgNWs [46-48].

\section{Materials and Methods}

\subsection{Materials}

The materials used in this study were silver nitrate $\left(\mathrm{AgNO}_{3}\right) 99 \%$ (Sigma-Aldrich Pte. Ltd., Science Park Drive, Singapore), PVP Mw. 55,000 g/mol (Sigma-Aldrich Pte. Ltd., Science Park Drive, Singapore), ethylene glycol (EG) 99.5\% (Merck kGaA, Darmstadt, Germany), propylene glycol (Merck kGaA, Darmstadt, Germany), ethanol 96\% (Merck $\mathrm{kGaA}$, Darmstadt, Germany), $\mathrm{FeCl}_{3} \cdot 6 \mathrm{H}_{2} \mathrm{O}$ (Sigma-Aldrich Pte. Ltd., Science Park Drive, Singapore) $0.04 \mathrm{M}$, silicon oil, deionized water, ice, and dry ice.

\subsection{Synthesis}

The synthesis of AgNWs by the polyol method occurs in three stages, namely the dissolution process, AgNWs synthesis, and centrifugation [6,48], as shown in Figure 6. The AgNWs synthesis was initiated by dissolving $2.994 \mathrm{~g}$ of PVP into $60 \mathrm{~mL}$ EG in an Erlenmeyer flask at $130{ }^{\circ} \mathrm{C}$ for $1 \mathrm{~h}$. Then, $4 \mu \mathrm{L}$ of $0.04 \mathrm{M} \mathrm{FeCl}_{3} \cdot 6 \mathrm{H}_{2} \mathrm{O}$ was added followed by the dropwise addition of $24 \mathrm{~mL}$ of $0.3 \mathrm{M} \mathrm{AgNO}_{3} / \mathrm{EG}$ for $2 \mathrm{~h}$ using a drop syringe with stirring at $350 \mathrm{rpm}$ for $2 \mathrm{~h}$. Then, the AgNWs samples were quenched in three different media, namely water, ice, and dry ice, and prickly heat to room temperature. After, the samples were washed with ethanol through a centrifugation tool for $10 \mathrm{~min}$, and then a vibration test was performed for $45 \mathrm{~min}$ using an ultrasonic cleaner [27]. 


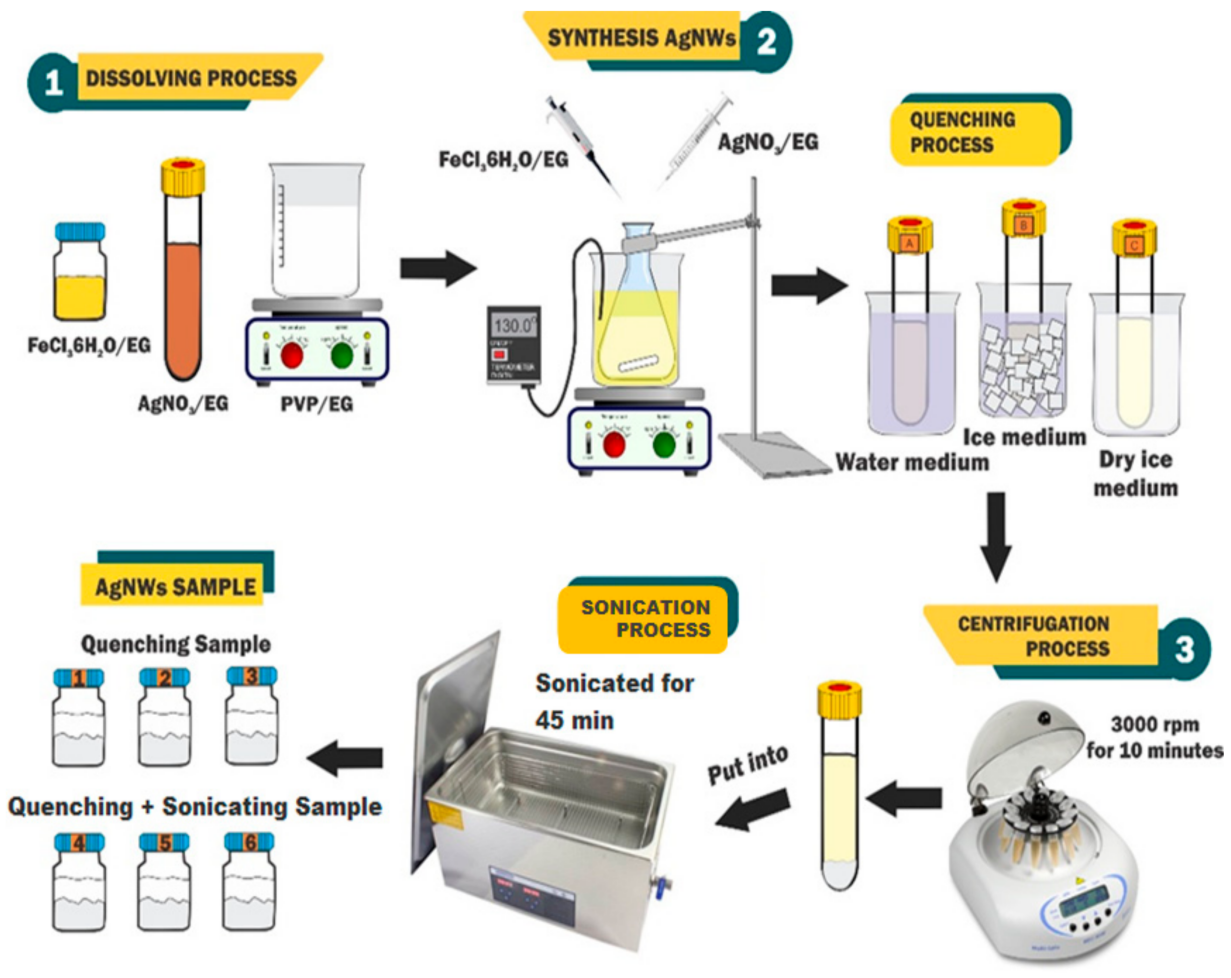

Figure 6. Synthesis of silver nanowires by polyol method.

\subsection{Characterization}

AgNWs physical parameter tests include tests of optical properties, morphology and size, and thermal properties. The optical properties test was carried out using a UV-Vis spectrophotometer (Shimadzu, UV-1700, Japan) at a wavelength of 300-800 nm. The morphological and size tests of the AgNWs were carried out using Scanning Electron Microscopy (SEM, JEOL JSM-6510, Japan) at a voltage of $20 \mathrm{kV}$. To further ascertain the size of the AgNWs, Transmission Electron Microscopy (TEM, JEOL 2010, JEOL, Tokyo, Japan) characterization was carried out at a voltage of $120 \mathrm{kV}$. Furthermore, the thermal properties test to determine the mechanical strength of AgNWs was carried out using Differential Thermal Analysis (DTA) and Thermogravimetric Analysis (TGA) of type DTG-60 (Shimadzu, Kyoto, Japan) from 0 to $500{ }^{\circ} \mathrm{C}$.

UV-Vis spectroscopy was used to determine the peak absorption of the AgNWs with a wavelength of 300-600 nm. SEM was used to determine the morphology and size of the AgNWs; the data was then analyzed using ImageJ software (open source developed by NIH and University of Wisconsin). DTA/TGA was performed to determine the thermal stability of the material. The temperature used was $500{ }^{\circ} \mathrm{C}$ to room temperature.

\section{Conclusions}

The effect of sonification or vibration on AgNWs from UV-vis results has a peak shift toward the red shift. The DTA results show that AgNWs have endothermic peaks at $110^{\circ} \mathrm{C}$ and exothermic peaks at 350 to $380^{\circ} \mathrm{C}$, and that the best thermal stability occurs in AgNWs quenched at $-80^{\circ} \mathrm{C}$. The quenching process in AgNW synthesis affects the length and diameter of the AgNWs. The lower the temperature of the quenching medium, the higher the mechanical strength and diameter of the AgNWs. The lower the temperature of the quenching medium, the smaller the percentage of total mass loss of the AgNWs. Here, we observed that the lower the temperature of the quenching medium, the shorter the length and the longer the diameter of the AgNWs.

Author Contributions: Conceptualization, J.J.; methodology, J.J.; software, M.W.S.; validation, J.J., M.W.S. and S.S.; formal analysis, J.J., S.S. and S.H.; investigation, J.J.; resources, J.J.; data curation, 
R.M.; writing—original draft preparation, J.J.; writing—review and editing, S.H.; visualization, J.J. and M.W.S.; supervision, J.J., R.M. and S.S.; project administration, M.W.S.; funding acquisition, J.J. and S.H. All authors have read and agreed to the published version of the manuscript.

Funding: This research was funding by Ministry of Research, Technology and Higher Education of the Republic of Indonesia via Institute for Research and Community Services of Universitas Lampung that has supported this work by providing a Profesorship research grant with contract number of 1516/UN26.21/PN/2020.

Data Availability Statement: The data presented in this study are available on request from the corresponding author.

Conflicts of Interest: The authors declare no conflict of interest.

Sample Availability: Not available.

\section{References}

1. Ganguly, S.; Mondal, S.; Das, P.; Bhawal, P.; Das, T.K.; Bose, M.; Choudhary, S.; Gangopadhyay, S.; Das, A.K.; Das, N.C. Natural saponin stabilized nano-catalyst as efficient dye-degradation catalyst. Nano-Struct. Nano-Objects 2018, 16, 86-95. [CrossRef]

2. Crisan, C.M.; Mocan, T.; Manolea, M.; Lasca, L.I.; Tăbăran, F.-A.; Mocan, L. Review on silver nanoparticles as a novel class of antibacterial solutions. Appl. Sci. 2021, 11, 1120. [CrossRef]

3. Zhang, P.; Lin, S.; Hu, J. Synthesis and characterization of size-controlled silver nanowires. Phys. Sci. Rev. 2018, 3, 20170084. [CrossRef]

4. Parente, M.; Van Helvert, M.; Hamans, R.F.; Verbroekken, R.; Sinha, R.; Bieberle-Hütter, A.; Baldi, A. Simple and fast high-yield synthesis of silver nanowires. Nano Lett. 2020, 20, 5759-5764. [CrossRef] [PubMed]

5. Lee, H.S.; Kim, Y.W.; Kim, J.E.; Yoon, S.W.; Kim, T.Y.; Noh, J.-S.; Suh, K.S. Synthesis of dimension-controlled silver nanowires for highly conductive and transparent nanowire films. Acta Mater. 2015, 83, 84-90. [CrossRef]

6. Junaidi, J.; Maulidiasani, K.; Triyana, K.; Khairurrijal, K. Thin films of silver nanowires for flexible, transparent, and conductive (FTC) electrodes. Int. J. Adv. Sci. Eng. Inf. Technol. 2020, 10, 137-144. [CrossRef]

7. Zhang, Q.; Wang, Q. Particle size distribution of silver nanoparticles in different water conditions. J. Mater. Environ. Sci. 2013, 4, 617-620.

8. Tan, D.; Jiang, C.; Li, Q.; Bi, S.; Song, J. Silver nanowire networks with preparations and applications: A review. J. Mater. Sci. Mater. Electron. 2020, 31, 15669-15696. [CrossRef]

9. Shi, Y.; He, L.; Deng, Q.; Liu, Q.; Li, L.; Wang, W.; Xin, Z.; Liu, R. Synthesis and applications of silver nanowires for transparent conductive films. Micromachines 2019, 10,330. [CrossRef]

10. Li, Y.; Guo, S.; Yang, H.; Chao, Y.; Jiang, S.; Wang, C. One-step synthesis of ultra-long silver nanowires of over $100 \mu \mathrm{m}$ and their application in flexible transparent conductive films. RSC Adv. 2018, 8, 8057-8063. [CrossRef]

11. Bao, J.; Wang, J.-X.; Zeng, X.-F.; Zhang, L.-L.; Chen, J.-F. Large-scale synthesis of uniform silver nanowires by high-gravity technology for flexible transparent conductive electrodes. Ind. Eng. Chem. Res. 2019, 58, 20630-20638. [CrossRef]

12. Chen, T.; Wang, H.; Yang, H.; Bai, S.; Guo, X. Mixed polyols synthesis of high aspect ratio silver nanowires for transparent conductive films. Mater. Res. Express 2018, 5, 066426. [CrossRef]

13. Jones, R.S.; Draheim, R.R.; Roldo, M. Silver nanowires: Synthesis, antibacterial activity and biomedical applications. Appl. Sci. 2018, 8, 673. [CrossRef]

14. Mirjalili, S.H.; Nateghi, M.R.; Kalantari-Fotooh, F. Preparation of silver nanowire/expanded polytetrafluoroethylene and polypropylene nanocomposites via all solution process method for antibacterial applications. J. Text. Inst. 2019, 111, 139-147. [CrossRef]

15. Wang, J.; Fang, Z.; Zhu, H.; Gao, B.; Garner, S.; Cimo, P.; Barcikowski, Z.; Mignerey, A.; Hu, L. Flexible, transparent, and conductive defrosting glass. Thin Solid Film. 2014, 556, 13-17. [CrossRef]

16. Kim, Y.; Lee, D.H.; Kim, N.-H.; Kim, J.-W. Flexible and transparent electrode based on silver nanowires and a urethane acrylate incorporating diels-Alder adducts. Mater. Des. 2015, 88, 1158-1163. [CrossRef]

17. Li, W.; Meredov, A.; Shamim, A. Coat-and-print patterning of silver nanowires for flexible and transparent electronics. npj Flex. Electron. 2019, 3, 19. [CrossRef]

18. Huang, Y.; Liao, S.; Ren, J.; Khalid, B.; Peng, H.; Wu, H. A transparent, conducting tape for flexible electronics. Nano Res. 2016, 9 , 917-924. [CrossRef]

19. He, W.; Ye, C. Flexible transparent conductive films on the basis of ag nanowires: Design and applications: A review. J. Mater. Sci. Technol. 2015, 31, 581-588. [CrossRef]

20. Ranasinghe, D.R.; Aryal, B.R.; Westover, T.R.; Jia, S.; Davis, R.C.; Harb, J.N.; Schulman, R.; Woolley, A.T. Seeding, plating and electrical characterization of gold nanowires formed on self-assembled DNA nanotubes. Molecules 2020, 25, 4817. [CrossRef]

21. Selzer, F.; Floresca, C.; Kneppe, D.; Bormann, L.; Sachse, C.; Weiß, N.; Eychmüller, A.; Amassian, A.; Müller-Meskamp, L.; Leo, K. Electrical limit of silver nanowire electrodes: Direct measurement of the nanowire junction resistance. Appl. Phys. Lett. 2016, 108, 163302. [CrossRef] 
22. Nair, N.M.; Pakkathillam, J.K.; Kumar, K.; Arunachalam, K.; Ray, D.; Swaminathan, P. Printable silver nanowire and pedot:PSS nanocomposite ink for flexible transparent conducting applications. ACS Appl. Electron. Mater. 2020, 2, 1000-1010. [CrossRef]

23. Ergun, O.; Coskun, S.; Yusufoglu, Y.; Unalan, H.E. High-performance, bare silver nanowire network transparent heaters. Nanotechnology 2016, 27, 445708. [CrossRef]

24. Jeong, G.-J.; Lee, J.-H.; Han, S.-H.; Jin, W.-Y.; Kang, J.-W.; Lee, S.-N. Silver nanowires for transparent conductive electrode to GaN-based light-emitting diodes. Appl. Phys. Lett. 2015, 106, 031118. [CrossRef]

25. Ganguly, S.; Das, P.; Bose, M.; Das, T.K.; Mondal, S.; Das, A.K.; Das, N.C. Sonochemical green reduction to prepare Ag nanoparticles decorated graphene sheets for catalytic performance and antibacterial application. Ultrason. Sonochem. 2017, 39, 577-588. [CrossRef]

26. Johan, M.R.; Aznan, N.A.K.; Yee, S.T.; Ho, I.H.; Ooi, S.W.; Singho, N.D.; Aplop, F. Synthesis and growth mechanism of silver nanowires through different mediated agents (CuCl2and $\mathrm{NaCl}$ ) polyol process. J. Nanomater. 2014, 2014, 105454. [CrossRef]

27. Junaidi; Yunus, M.; Triyana, K.; Harsojo; Suharyadi, E. Chloride ion addition for controlling shapes and properties of silver nanorods capped by polyvinyl alcohol synthesized using polyol method. In Proceedings of the 3rd International Conference on Advanced Materials Science and Technology (ICAMST 2015), Semarang, Indonesia, 6-7 October 2016; AIP Publishing: Melville, NY, USA, 2016; Volume 1725, p. 20031. [CrossRef]

28. Lee, J.-Y.; Shin, D.; Park, J. Fabrication of silver nanowire-based stretchable electrodes using spray coating. Thin Solid Film. 2016, $608,34-43$. [CrossRef]

29. Feliciano, J.; Martínez-Iñesta, M.M. Synthesis and characterization of Pd, Cu, and Ag nanowires in anodic alumina membranes using solid state reduction. Mater. Lett. 2012, 82, 211-213. [CrossRef]

30. Fahad, S.; Yu, H.; Wang, L.; Nazir, A.; Ullah, R.S.; Naveed, K.-U.-R.; Elshaarani, T.; Amin, B.U.; Khan, A.; Mehmood, S. Synthesis of silver nanowires with controlled diameter and their conductive thin films. J. Mater. Sci. Mater. Electron. 2019, 30, 12876-12887. [CrossRef]

31. Sachse, C.; Müller-Meskamp, L.; Bormann, L.; Kim, Y.H.; Lehnert, F.; Philipp, A.; Beyer, B.; Leo, K. Transparent, dip-coated silver nanowire electrodes for small molecule organic solar cells. Org. Electron. 2013, 14, 143-148. [CrossRef]

32. Mi, H.-Y.; Li, Z.; Turng, L.-S.; Sun, Y.; Gong, S. Silver nanowire/thermoplastic polyurethane elastomer nanocomposites: Thermal, mechanical, and dielectric properties. Mater. Des. 2014, 56, 398-404. [CrossRef]

33. Margulis, G.Y.; Christoforo, M.G.; Lam, D.; Beiley, Z.M.; Bowring, A.R.; Bailie, C.D.; Salleo, A.; McGehee, M.D. Spray deposition of silver nanowire electrodes for semitransparent solid-state dye-sensitized solar cells. Adv. Energy Mater. 2013, 3, 1657-1663. [CrossRef]

34. Moreno, I.; Navascues, N.; Irusta, S.; Santamaria, J. Silver nanowires / polycarbonate composites for conductive films. IOP Conf. Ser. Mater. Sci. Eng. 2012, 40, 012001. [CrossRef]

35. Peng, H.; Jiang, H.; Tu, S.; Zhang, S.; Ren, E.; Yan, B.; Yang, Q.; Chen, S. High-performance and ultraflexible PEDOT/silver nanowires/graphene films for electrochromic applications. Opt. Lett. 2020, 45, 2443-2446. [CrossRef]

36. Lin, J.-Y.; Hsueh, Y.-L.; Huang, J.-J.; Wu, J.-R. Effect of silver nitrate concentration of silver nanowires synthesized using a polyol method and their application as transparent conductive films. Thin Solid Film. 2015, 584, 243-247. [CrossRef]

37. Kim, T.; Canlier, A.; Kim, G.H.; Choi, J.; Park, M.; Han, S.M. Electrostatic spray deposition of highly transparent silver nanowire electrode on flexible substrate. ACS Appl. Mater. Interfaces 2013, 5, 788-794. [CrossRef]

38. Preston, C.; Xu, Y.; Han, X.; Munday, J.N.; Hu, L. Optical haze of transparent and conductive silver nanowire films. Nano Res. 2013, 6, 461-468. [CrossRef]

39. Selzer, F.; Weiß, N.; Bormann, L.; Sachse, C.; Gaponik, N.; Müller-Meskamp, L.; Eychmüller, A.; Leo, K. Highly conductive silver nanowire networks by organic matrix assisted low-temperature fusing. Org. Electron. 2014, 15, 3818-3824. [CrossRef]

40. Mao, H.; Feng, J.; Ma, X.; Wu, C.; Zhao, X. One-dimensional silver nanowires synthesized by self-seeding polyol process. J. Nanoparticle Res. 2012, 14, 1-15. [CrossRef]

41. Rajesh, D.; Sunandana, C.; Desapogu, R. Controlled formation of porous silver nanowires. Chem. Phys. Lett. 2014, 610-611, 363-368. [CrossRef]

42. Cheng, T.; Zhang, Y.; Lai, W.-Y.; Chen, Y.; Huang, W. A rapid synthesis of high aspect ratio silver nanowires for high-performance transparent electrodes. Chin. J. Chem. 2014, 33, 147-151. [CrossRef]

43. Junaidi; Triyana, K.; Hui, H.; Wu, L.Y.L.; Suharyadi, E.; Harsojo. The silver nanowires synthesized using different molecule weight of polyvinyl pyrrolidone for controlling diameter and length by one-pot polyol method. In Proceedings of the 2016 Conference on Fundamental and Applied Science for Advanced Technology (CONFAST 2016), Yogyakarta, Indonesia, 25-26 January 2016; AIP Publishing: Melville, NY, USA, 2016; Volume 1746, p. 20014. [CrossRef]

44. Langley, D.; Giusti, G.; Mayousse, C.; Celle, C.; Bellet, D.; Simonato, J.-P. Flexible transparent conductive materials based on silver nanowire networks: A review. Nanotechnology 2013, 24, 452001. [CrossRef]

45. Lee, J.-H.; Shin, H.-S.; Noh, Y.-J.; Na, S.-I.; Kim, H.-K. Brush painting of transparent PEDOT/Ag nanowire/PEDOT multilayer electrodes for flexible organic solar cells. Sol. Energy Mater. Sol. Cells 2013, 114, 15-23. [CrossRef]

46. Wang, J.; Jiu, J.; Araki, T.; Nogi, M.; Sugahara, T.; Nagao, S.; Koga, H.; He, P.; Suganuma, K. Silver nanowire electrodes: Conductivity improvement without post-treatment and application in capacitive pressure sensors. Nano-Micro Lett. 2015, 7, 51-58. [CrossRef] 
47. Huang, H. Fabrication of three-dimensional sandwich-like silver nanowire network coated bilayer graphene nanostructures for flexible display. Appl. Opt. 2020, 59, 9878-9883. [CrossRef]

48. Junaidi, J.; Triyana, K.; Suharyadi, E.; Harsojo; Wu, L.Y. The roles of polyvinyl alcohol (PVA) as the capping agent on the polyol method for synthesizing silver nanowires. J. Nano Res. 2017, 49, 174-180. [CrossRef] 